\title{
Correlation between the use of the accommodation and symptoms of asthenopia in hyperopic patients
}

\author{
Correlação entre o uso da acomodação e sintomas \\ de astenopia em pacientes hipermétropes
}

Juan Carlos Luna da Costa ${ }^{1}$, lan Beltrão de Sá Martins ${ }^{1}$, Larissa Tavares Albuquerque Nóbrega ${ }^{1}$, Maria Odília Navarro Medeiros ${ }^{1}$, Luciana Maria Palitot ${ }^{1}$, Marília Bezerra Cavalcanti Dias ${ }^{1}$ Tarcízio José Dias ${ }^{1}$

\begin{abstract}
Purpose: The objective of this paper was to compare the symptoms of asthenopia in patients at different levels of hyperopia and corrected for different accommodative efforts. Methods: This study is an experimental design and quantitative approach. Sixty-nine hyperopic patients aged between 15 and 40 were selected. Individuals with a diagnosis of accommodative insufficiency and paralysis, accommodative spasm or any type of ocular deviation were excluded. Subjects were randomly divided into four groups. Each one performed a nearvision task with different corrective lenses, varying the value of the accommodative effort. Results: There is significant reduction in the asthenopia score during the near-vision task when leaving $35 \%$ or more of the amplitude of accommodation in reserve. The linear regression showed that the variables total hyperopia $(r=0.109)$ and the difference between static and dynamic refraction $(r=0.135)$ did not obtain significant linear relationship to the asthenopia score. Conclusions: There is significant reduction in the asthenopia score when leaving $35 \%$ or more of the amplitude of accommodation in reserve. The symptoms of asthenopia are not associated to the severity of the hyperopic refractive error. The search for symptoms before the near vision task, using a questionnaire, related to the symptoms during the accommodative effort task, revealing the importance of searching for complaints about asthenopia during anamnesis, which can help ophthalmologists with prescriptions of glasses for hyperopic patients with asthenopia.
\end{abstract}

Keywords: Accommodation, ocular; Hyperopia; Asthenopia; Refraction, ocular; Eyeglasses

\section{RESUMO}

Objetivos: O presente estudo objetivou avaliar os efeitos do esforço acomodativo e do poder do erro refrativo nos sintomas de astenopia. Métodos: Trata-se de um modelo de estudo experimental e abordagem quantitativa, cuja amostra consistiu de 69 pacientes hipermetropes entre 15 e 40 anos de idade. Foram excluídos os indivíduos com diagnóstico de insuficiência ou paralisia da acomodação, espasmo de acomodação ou qualquer tipo de desvio ocular. Os pacientes foram alocados aleatoriamente em quatro grupos. Cada grupo realizou o trabalho de visão para perto com correções diferentes, variando o valor do esforço acomodativo. Resultado: Houve melhora significativa dos sintomas de astenopia com correções que proporcionaram mais de $35 \%$ da amplitude de acomodação em reserva. Não houve relação estatisticamente significativa entre os sintomas e o valor do erro refrativo. Conclusão: Há uma redução significativa dos sintomas quando os pacientes mantêm 35 \% ou mais de sua acomodação em reserva. Os sintomas de astenopia não estão associados à gravidade do defeito hipermetrópico. A pesquisa de sintomas antes do teste, através de um questionário, foi o fator que melhor se relacionou com os sintomas durante o teste de visão para perto, revelando a importância da pesquisa das queixas de astenopia durante anamnese na prescrição de lentes para visão de perto.

Descritores: Acomodação ocular; Hiperopia; Astenopia; Refração ocular; Óculos

${ }^{1}$ Centro Oftálmico Tarcízio Dias, João Pessoa, Paraíba, Brazil.

The authors declare no conflicts of interest

Received for publication 29/09/2014 - Accepted for publication 08/03/2015

Rev Bras Oftalmol. 2015; 74 (4): 225-30 


\section{INTRODUÇãO}

$\mathbf{H}$ yperopia is the condition of the eye where incoming rays of light reach the retina before they converge into a focused image. Total hyperopia is divided into latent hyperopia and manifest hyperopia. Latent hyperopia is the one which is physiologically supplanted by the tonus of the ciliary muscles. Manifest hyperopia is divided into facultative hyperopia and absolute hyperopia. Facultative hyperopia is the one which can be overcome by the accommodative effort, while this is not possible in the case of the absolute hyperopia ${ }^{(1)}$.

For several ophthalmologists, the prescription for the near vision is based on the claim that only half or two-thirds of an individual's amplitude of accommodation is sustainable for an extended period of time ${ }^{(2)}$. Donders (1972) recommended, for the correction of hyperopia, the value of the manifest hyperopia added to a fourth of the latent hyperopia ${ }^{(3)}$. A rule of thumb which received wide acceptance is that the lens used for near vision should allow that half of the patient's amplitude of accommodation remain in reserve ${ }^{(4)}$.

The younger the patient, the more active is the accommodation; therefore, less correction for the hyperopia is needed. In normal individuals, right after birth the hyperopia is about 2 to 3 diopters. It can increase slightly in the first years of life, but it rapidly and gradually diminishes according to the somatic growth until after the puberty, in which the individuals tend to become emmetropic. After the growth period, refraction tends to remain stationary. In old age, the tendency to hyperopia is greater, due to modifications in the curvature and in the refraction indexes of the crystalline lens layers ${ }^{(1,5)}$.

There is also an apparent increase of hyperopia due to progressive insufficiency of accommodation. With the decrease of the ciliary muscle tonus, part of the latent hyperopia also manifests itself and with the reduction of the accommodation capacity, most of the facultative hyperopia becomes absolute. Therefore, in the beginning of life, unless the error is very high, the accommodation capacity is able to correct it entirely, if absolute hyperopia is absent. After the age of 65 virtually all the error becomes absolute ${ }^{(4)}$.

The symptoms of eye strain are, in part, due to extreme accommodation and to the extra convergence effort. Asthenopia is the term used to describe the sensation of extreme effort and weakness or eye fatigue derived from the use of vision. It is a common manifestation in many patients with convergence insufficiency, accommodation insufficiency, refractive error and strabismus. Its symptoms are headache, diplopia, difficulty in focusing the image, fatigue, reading problems, blurred vision ${ }^{(6)}$.

Accommodative fatigue can be described as the reduction of the performance of the accommodation system due to a prolonged or repetitive accommodative effort ${ }^{(7)}$. In near vision, the temporary insufficiency of the ciliary muscle to maintain contraction can result in visual impairment, on the other hand extreme accommodation or spasm of the ciliary muscle, may cause an artificial condition of myopia ${ }^{(8)}$.

Accommodation is a key factor in the correction of hyperopia ${ }^{(5)}$, which motivated us to construct a diagram (diagram $J)$ to correlate the refractive error with the amplitude of accommodation and find the ideal value of the most comfortable reading prescription for the hyperopic patients. In the diagram, the $j$ value can be found relating the values of total hyperopia of the patient to his accommodation and represents the comfortable refraction for near vision. This way, the diagram can be constructed according to the adequate refraction to hold a determinate fraction of the accommodation in reserve. In other words, the fraction of the accommodation not used by the eyes while fixing in a point in space, avoiding over or undercorrection. The $j(50)$ means the value in the diagram calculated to leave in reserve $50 \%$ of the patient's accommodation. The value of $j$ can be found through the following equation, in which $j c$ is the value of prescription for certain accommodative reserve $\mathrm{C} ; \mathrm{D}$ is the value of the hyperopia in diopters; $\mathrm{P}$ is the additional dioptric power for near vision; $\mathrm{AA}$ is the amplitude of accommodation in diopters and $\mathrm{C}$ is the value of the accommodative reserve in percentage:

$$
j(\mathrm{C})=\mathrm{D}+\mathrm{P}-\left[\mathrm{AA}(100-\mathrm{C}) \cdot 10^{-2}\right]
$$

The deduction of this equation is based on the maintenance of a fraction of the accommodation during near vision effort. Hence, near vision requires the total correction $\mathrm{D}$ summed to the value of $\mathrm{P}$ ( 3 diopters in usual conditions), but in these circumstances the prescription of lens would cancel the accommodative effort. The reduction of this value would imply in a progressive increase in the use of accommodation to the maximum of the individual's accommodation capacity. An evidence of this effort would be the increase of the reduction factor "AA(100-C).10"-2". Therefore, it was observed that the higher the accommodative reserve $\mathrm{C}$, the lower the accommodative effort, in a way that a correction $j(100)$ would cancel the reduction factor and, consequently, accommodation.

This equation explains why individuals with high amplitude of accommodation tend to tolerate higher degrees of hyperopia. For instance, a five-year-old child's amplitude of accommodation is about $16 \mathrm{D}$. Considering that this child is hyperopic and his/her hyperopia measures two diopters, in order to hold $50 \%$ of his/her accommodation in reserve while he/she reads from a distance of $33 \mathrm{~cm}$, the ideal prescription would be: $j(50)=+2+3-\left[16(100-50) \cdot 10^{-2}\right]=-3 \mathrm{D}$. The value of $-3 \mathrm{D}$ implies that, at this moment, it is not necessary to correct this patient's near vision, while symptoms are absent. With aging and loss of accommodation, the hyperopic patients tend to present symptoms of asthenopia. Thus, a patient with the same 2 diopters of hyperopia will need $+1,5 \mathrm{D}$ correction when his/her amplitude is reduced to 7D (which happens approximately at 30 years of age), to ensure that $50 \%$ of his/her accommodation remains in reserve and the patient will be able to read comfortably.

Despite the fact that, according to many ophthalmologists, the prescription for near vision is based on the claim that only half or two-thirds of the amplitude of accommodation is sustainable for an extended period of time, a research developed by Wolffsohn et al. showed that adults' accommodation system is robust and resistant to fatigue during an intensive and prolonged task ${ }^{(2)}$. Besides, a greater proportion of the amplitude of accommodation can be exercised in a continuous way, in spite of what was suggested previously. Alves suggests the correction of hyperopia for occasional use, for reading or any other activity that requires accommodative effort, in those cases where there is difficulty to relate the symptoms ${ }^{(5)}$.

Based on this dissent, one of the objectives of the present article is to compare the symptoms of accommodative effort in patients with correction for $j(20), j(35), j(50) \mathrm{e}_{\mathrm{e}} j(60)$ during a sustained and intensive task for near vision. 
The main objective of this paper was to compare the symptoms of asthenopia in patients at different levels of hyperopia and corrected for different accommodative efforts. The specific objectives were: to compare the relation between the level of asthenopia before and after near vision task; to evaluate the symptoms of accommodative effort in patients with correction for $j(20), j(35), j(50)$ e $j(60)$; to relate the symptoms of asthenopia with the value of refractive error; to construct a diagram to guide the ophthalmologist in prescribing glasses for near vision.

\section{MethodS}

This study is an experimental design and quantitative approach. The sample consists of hyperopic patients treated at Instituto Visão para Todos (IVPT) of Centro Oftálmico Tarcízio Dias, in João Pessoa - State of Paraíba, Brazil, from January, 2013 to April, 2014.

Hyperopic patients aged between 15 and 40 were selected. Individuals with a diagnosis of accommodative insufficiency and paralysis, accommodative spasm or any type of ocular deviation were excluded from the study.

All the individuals were carefully evaluated with regard to the amplitude of accommodation, refractive error, visual acuity and ocular deviation. The push-up method was adopted in order to obtain the amplitude of accommodation. The method consists of Snellen optotypes for near vision $40 \mathrm{~cm}$ distant from the eye with corrected ametropia. In this method the patient is oriented to find the best optotype of the chart that could be clearly seen. Then the chart is placed closer to the patient until a blurred vision of the letters is obtained. This distance is converted into diopters, which corresponds to its amplitude of accommodation ${ }^{(9)}$.

Automated refraction without cyclopegia was conducted with the Huvitz MRK-3100 Premium refractor. The total hyperopia was evaluated with the same refractor $40 \mathrm{~min}$ after the instillation of Cyclopentolate 1\%. Over recent years, several studies comparing the cycloplegic effect of various drugs to the required number of drops have proved that the instillation of a drop of Cyclopentolate $1 \%$ is sufficient to obtain adequate cycloplegia ${ }^{(10-13)}$. The individuals were requested to return one week after the refractive evaluation for an accommodative effort task. Before the near-vision task, all the individuals answered the asthenopia symptoms survey (ASS), a questionnaire about symptoms of asthenopia, which was translated to Portuguese. The questionnaire consists of eight questions, which involve symptoms during near-vision task (discomfort, headache, eye pain, blurred vision, double vision, burning sensation, eye strain). Each symptom is graded in five points according to its severity ${ }^{(14)}$.

The participants were randomly divided into four groups. Each one performed the near-vision task with different corrections: $j(20), j(35), j(50)$ and $j(60)$. Diagrams that relate the amplitude of accommodation with the total hyperopia were used to find a prescription for each group. The right eye underwent a 20-minute near-vision task, consisting of the use of a computer monitor $33 \mathrm{~cm}$ distant from the eye, showing a $2.0 \mathrm{~mm}$ wide and $3.0 \mathrm{~mm}$ long rectangular white line on a black background. The rectangle was programmed to randomly move, every 4 seconds in the same position of its geometric center, in the following directions: vertical, horizontal, and diagonal. The patients were requested to read the rectangle and inform its direction. This modality was chosen because of the fact that it was ensured that the individuals evaluated kept focusing on their target during most part of the time in order that the blur could be identified as the patient's difficulty to define the directions. Furthermore, the eye movement effort, which is commonly used in reading, was eliminated in order to evaluate the symptoms related solely to accommodation. By means of monocular testing, we minimized the convergence effort. In order to minimize the dry-eye effect, all the patients received one drop of carmellose sodium $5 \mathrm{mg} / \mathrm{ml}$ on both eyes before the near-vision task. Astigmatism was completely corrected with cylindrical lens. The average luminance in the monitor position was of 290 Lux, measured with the digital CEL luxmeter, model LD-511.

The data was registered on a formulary containing information about the symptoms experienced (headache, blurred vision, double vision, pain, burning sensation, eye strain) and the moment when they occurred. Each of the five symptoms was classified into a scale from 0 to 1 , taking into account the time (T) when the symptom appeared. Thus, punctuation 0 means that the symptom did not occur during the 20-minute test; the punctuation tends to the maximum of 1 when the symptom occurs at the very beginning of the test. The resulting asthenopia score was the sum of the punctuation of all the symptoms:

Asthenopia Score during the task $=\Sigma(1-\mathrm{T} / 20)$.

The IBM SPSS Statistics ${ }^{\circledR}$ software version 18 for Windows was used in the data analysis. ANOVA (analysis of variance), Turkey HSD test and linear regression were used. A significance level of $5 \%$ was adopted.

The project was approved by the Research Ethics Committee from Paraíba-Brazil (Protocol ID: 652.767). The patients' identification data were kept confidential during their collection and they were not exposed in the study. Informed consent was obtained.

\section{RESULTS}

Sixty-nine individuals were evaluated (30 male and 39 female). The average age was 26.77, with standard deviation of 6.975 .

The linear regression showed that the variables age $(r=$ $0.006)$, total hyperopia $(r=0.109)$ and the difference between static and dynamic refraction measured by autorefractor $(\mathrm{r}=$ 0.135 ) did not obtain significant linear relationship to the asthenopia score. The factor that contributed the most to the prediction of the symptoms was the Asthenopia Symptoms Survey ASS $(r=0.39)$, which corresponded to a direct and positive relation (Figure 1).

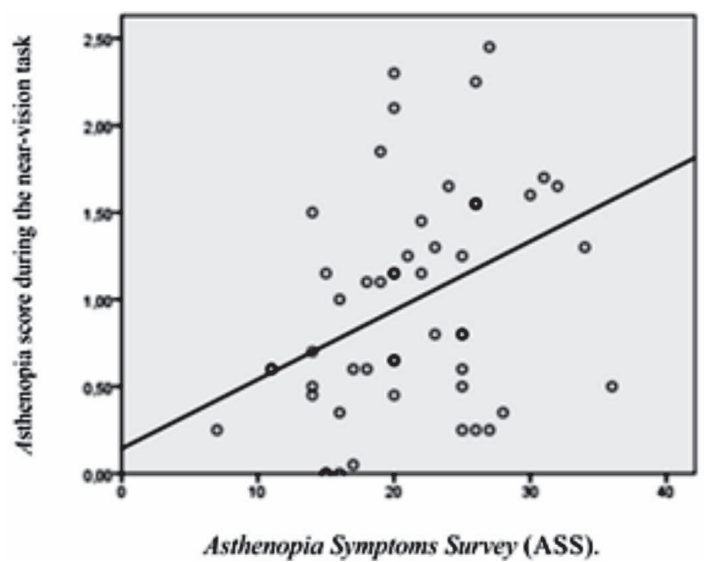

Figure 1: Graph of linar regression that shows the relation between the asthenopia symptoms score during the test $(r=0,39)$ and the Asthenopia Symptoms Survey (ASS). 
There was not a linear relationship between the groups and the asthenopia score during the task, but there was a significant decrease in the asthenopia score between the $j_{(20)}$ and $j_{(35)}$ groups, remaining unchanged after the $j_{(35)}$ (Figure 2).

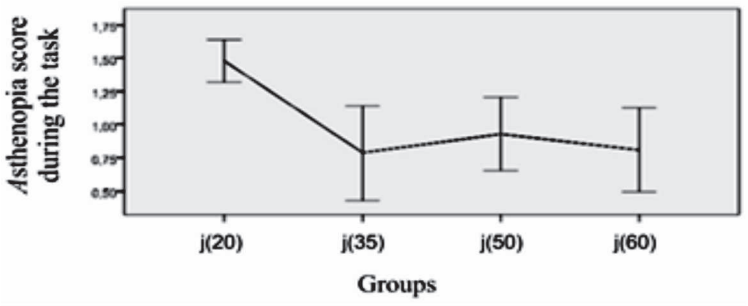

Figure 2: Graph the relates the symptoms scores during the nearvision task (mean and confidence interval) the groups tested.
Analysis of variance (one-way ANOVA) and Turkey HSD test revealed a statistical difference between level of accommodation and the asthenopia score $(\mathrm{F}$-value $=5.553 ; \mathrm{p}=$ $0.002)$. The tests show difference between groups $j(20)$ and $j(35)(\mathrm{p}=0.03)$. ANOVA also shows difference between $j(20)$ and $j(50)(\mathrm{p}=0.033)$. Groups $j(20)$ and $j(60)$ were statistically different as well $(\mathrm{p}=0.005)$. But there was no difference in the following analysis: $j(35)$ versus $j(50)(\mathrm{p}=0,870), j(35)$ versus $j(60)(\mathrm{p}=0.999), j(50)$ versus $j(60)(\mathrm{p}=0.931)$ (Table 1$)$. The $j(20)$ group was paired with the other groups concerning their gender and age, without interference of such factors. Analysis of variance (one-way ANOVA) showed no significant difference between groups concerning the intensity of hyperopia (F-value $=1.445 ; \mathrm{p}=0.238$ ).

Table 1

Relation between the level of accommodation and the variables age, gender and asthenopia score during the nearvision task. One-way ANOVA showed difference between group $j_{(20)}$ and the other groups concerning the asthenopia score (F-value $=5,553 ; \mathrm{p}=0,002)$.

\begin{tabular}{|c|c|c|c|c|c|}
\hline \multirow{2}{*}{ Group } & \multirow[t]{2}{*}{$\mathbf{n}$} & \multirow{2}{*}{$\begin{array}{c}\text { Age in years } \\
(\text { mean } \pm \text { SD) }\end{array}$} & \multicolumn{2}{|c|}{ Gender } & \multirow{2}{*}{$\begin{array}{l}\text { Asthenopia score during the task } \\
(\text { mean } \pm \text { SD) }\end{array}$} \\
\hline & & & $\mathbf{M}$ & $\mathbf{F}$ & \\
\hline $20 \%$ of accommodation in reserve: $j(20)$ & 17 & $27.80( \pm 6.66)$ & 8 & 9 & $1.479( \pm 0.31)$ \\
\hline $35 \%$ of accommodation in reserve: $j(35)$ & 19 & $30.13( \pm 5.18)$ & 7 & 12 & $0.786( \pm 0.735)$ \\
\hline $50 \%$ of accommodation in reserve: $j(50)$ & 17 & $24.93( \pm 7.92)$ & 8 & 9 & $0.932( \pm 0.534)$ \\
\hline
\end{tabular}

\section{Discussion}

The value of total hyperopia and the difference between the pre-cycloplegia and the post-cycloplegia refraction measured by the autorefractor were not associated to the symptoms presented during near vision effort. In his book, Duke-Elder states that symptoms do not appear in the proportion of severity of causal defect. The symptoms vary from individual to individual, reaching surprising levels without any apparent cause ${ }^{(1)}$.

Among the variables of the study, the one that contributed the most to the linear prediction of the symptoms was the Asthenopia Symptoms Survey (ASS). The pre-test complaint scores had a positive relation with the complaints during the test, regardless of the group tested. Thus, it is possible to conclude that some research on the symptoms of asthenopia during anamnesis is valid in order to help in the refraction and prescription of glasses for near vision.

There was no linear relationship between the treatment groups and the asthenopia score during the near vision task. Nevertheless, it could be concluded, from the results, that the prescription of lenses over $j_{(35)}$ considerably reduces the symptoms of asthenopia. Hence, there are no guarantees that the prescription of highly positive lenses, such as the prescription over $j_{(50)}$, will reduce more the patients' symptoms of asthenopia. We will illustrate the findings of the results into the following example: a 25-year-old individual (amplitude of accommodation of $8.5 \mathrm{D}$ ), with total hyperopia of $+3.0 \mathrm{D}$ spherical, has a correction of $+0.50 \mathrm{D}$ spherical in diagram $\mathrm{J}_{35}$ (Figure 3 ); the same individual presents a correction of $+1.75 \mathrm{D}$ spherical in diagram $\mathrm{J}_{50}$ for near vision lenses. The results pointed out significant improvement in $+0.50 \mathrm{D}$ or over lenses prescription. The prescription of highly positive lenses, namely over $+1.75 \mathrm{D}$, does not ensure improvement in relation to $+0.50 \mathrm{D}$.

Therefore, it is possible to infer that, in isolation, the power of accommodation does not explain the symptoms of asthenopia in a linear way. The use of extrinsic muscles was minimized by the test methodology, reducing the biases of the variable in the study. Several studies in the medical literature search for other factors as the causes of eye strain. Studies have shown the effects of psychological and environmental factors, such as stress at work, burnout, luminous intensity, thermal comfort in the ocular complaints at work ${ }^{(15-17)}$. The discovery of this effect may have an ergonomic influence on health, safety and comfort conditions.

The complaints during the test could be interpreted as the result of the uninterrupted use of accommodation for $20 \mathrm{~min}$. It is important that longer accommodative effort tests be performed and that new studies aim at evaluating the appearance of symptoms due to prolonged accommodative effort or with pauses for resting.

We conclude, therefore, that the accommodative effort, in isolation, does not explain the symptoms presented by patients; however, there is significant reduction in the asthenopia score when leaving $35 \%$ or more of the amplitude of accommodation 
in reserve. It was also concluded that the symptoms of asthenopia are not associated to the severity of the hyperopic refractive error. The search for symptoms before the near vision task was the factor that correlated the most with the symptoms during the accommodative effort test, revealing the importance of searching for complaints about asthenopia during anamnesis, which can help ophthalmologists with prescriptions of glasses for hyperopic patients with asthenopia.

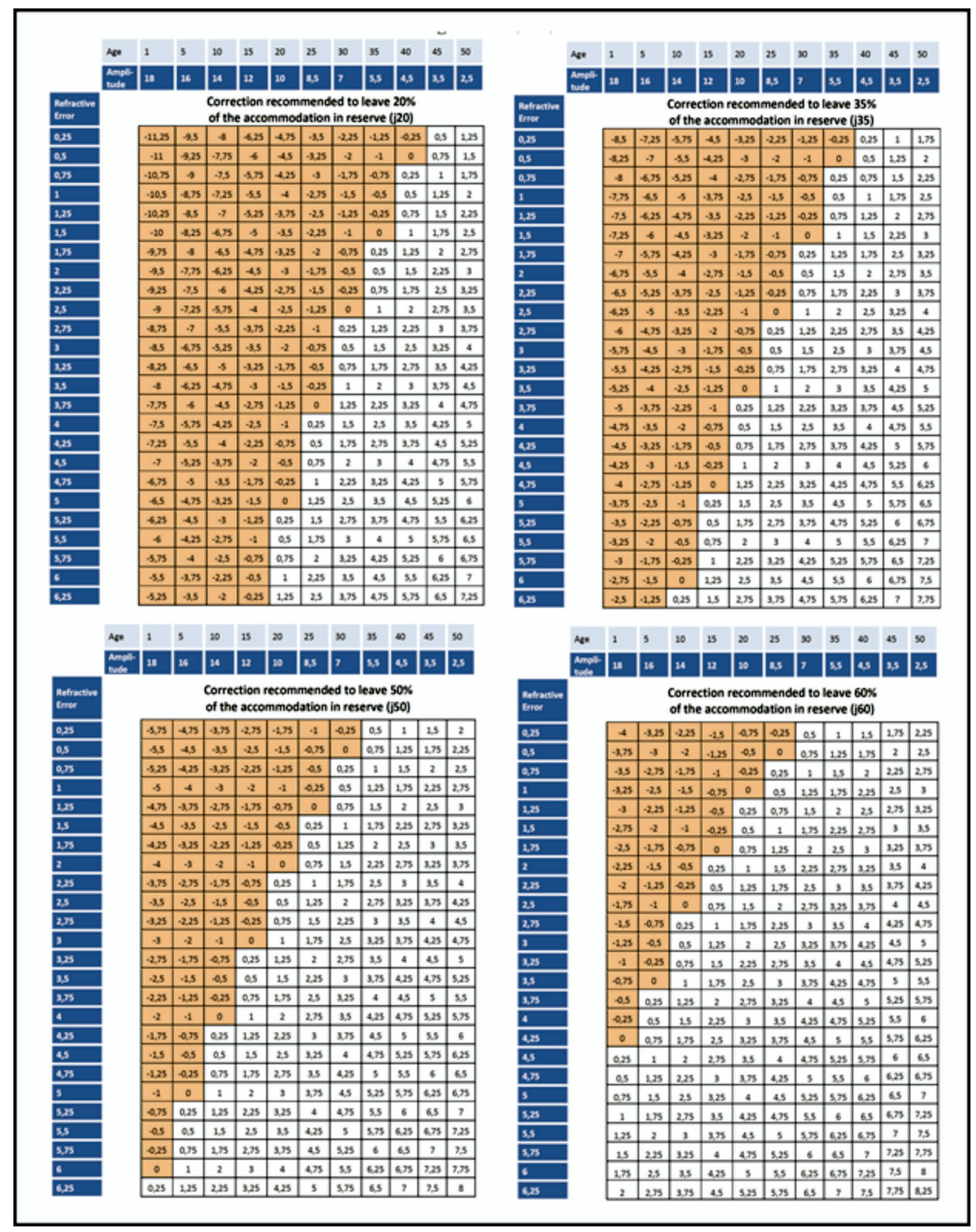

Figure 3: Diagrams $J(20), J(35), J(50)$ and $J(60)$. Colored cell: diopter is zero or negative, it may not be prescribed for hyperopia. Blank cell: diopter is positive, it may be prescribed for hyperopia. 


\section{ACKNOWLEDGEMENTS}

We are very grateful to translators Rodrigo Araújo e Castro and Raquel Rossini Martins Cardoso.

\section{REFERENCES}

1. Duke-Elder S. Refração Prática. Rio de Janeiro: Rio Med Livros; 1997.

2. Wolffsohn JS, Sheppard AL, Vakani S. Davies LN. Accommodative amplitude required for sustained near work. Ophthalmic Physiol Opt. 2011;31(5):480-6.

3. Donders FC. On the anomalies of accommodation and refraction of the eye. Boston: Milford House; 1972

4. Yanoff M, Duker JS. Oftalmologia. $3^{\mathrm{a}}$ ed. Rio de Janeiro: Elsevier; 2011.

5. Alves AA. Refração. 5a ed. Rio de Janeiro: Cultura Médica, 2008.

6. Abdi S, Lennerstrand G, Pansell T, Rydberg A. Orthoptic findings and asthenopia in a population of Swedish schoolchildren aged 6 to 16 years. Strabismus. 2008;16(2):47-55.

7. Hasebe S, Graf EW, Schor CM. Fatigue reduces tonic accommodation. Ophthalmic Physiol Opt. 2001;21(2):151-60.

8. Kasthurirangan S, Vilupuru AS, Glasser A. Amplitude dependent accommodative dynamics in humans. Vision Res. 2003;43(27):2945-56.

9. Duane A. Normal values of the accommodation at all ages. JAMA. 1912; 59(2):1010-13.

10. Celebi S, Aykan U. The comparison of cyclopentolate and atropine in patients with refractive accommodative esotropia by means of retinoscopy, autorefractometry and biometric lens thickness. Acta Ophthalmol Scand. 1999;77(4):426-9.
11. Hertwig RV, Netto AL, Souza-Dias CR. Acomodação residual sob o efeito cicloplégico do cloridrato de ciclopentolato a $1 \%$. Arq Bras Oftalmol. 1994;57(6):407-10,

12. Stolovitch C, Loewenstein A, Nemmet P, Lazar M. Atropine cycloplegia: how many instillations does one need? J Pediatr Ophthalmol Strabismus. 1992;29(3):175-6.

13. Pinheiro RK, Netto AL . Estudo comparativo da acomodação residual após instilação de colírios de tropicamida a $1 \%$, ciclopentolato a $1 \%$ e associação de tropicamida a $1 \%+$ ciclopentolato a 1\%. Arq Bras Oftalmol. 2000;63(6): 475-9.

14. Chatterjee D, Kothari M, Mody K. Anomalies of accommodation, fusion and refraction in patients with low asthenopia symptom survey score. AIOC Proceedings; 2010.

15. Ostrovsky A, Ribak J, Pereg A, Gaton D. Effects of job-related stress and burnout on asthenopia among high-tech workers. Ergonomics. 2012;55(8):854-62.

16. Azmoon H, Dehghan H, Akbari J, Souri S. The relationship between thermal comfort and light intensity with sleep quality and eye tiredness in shift work nurses. J Environ Public Health. 2013;2013:639184.

17. Ustinaviciene R, Januskevicius V. Association between occupational asthenopia and psycho-physiological indicators of visual strain in workers using video display terminals. Med Sci Monit, 2006; 12(7): CR296-301.

\section{Corresponding author}

Rua José Faustino Cavalcanti, 700, Pedro Gondim, João Pessoa, Paraíba, Brazil. Zip code: 58031180.

Phone: +55 8388082328 .

E-mail: juangba@uol.com.br. 